\title{
Detection of infectious bovine rhinotracheitis in natural cases of bovine abortion by PCR and histopathology assays
}

\author{
Farhang Sasani ${ }^{1,}$, , Aida Vazirian², Javad Javanbakht ${ }^{1}$, Mehdi Aghamohammd Hassan ${ }^{3}$ \\ ${ }^{1}$ Department of Pathology, Faculty of Veterinary Medicine, University of Tehran,Tehran, Iran \\ ${ }^{2}$ Faculty of Veterinary Medicine, University of Tehran, Tehran, Iran \\ ${ }^{3}$ Department of Clinical Science, Faculty of Veterinary Medicine, University of Tehran,Tehran, Iran
}

\section{Email address:}

Fsasani@ut.ac.ir (F. Sasani)

To cite this article:

Farhang Sasani, Aida Vazirian, Javad Javanbakht, Mehdi Aghamohammd Hassan. Detection of Infectious Bovine Rhinotracheitis in Natural Cases of Bovine Abortion by PCR and Histopathology Assays. American Journal of Clinical and Experimental Medicine. Vol. 1, No. 2, 2013, pp. 35-39. doi: 10.11648/j.ajcem.20130102.11

\begin{abstract}
Bovine herpesvirus 1 (BHV-1), the causative agent of infectious bovine rhinotracheitis (IBR), is considered to be the most common viral pathogen found in bovine. Bovine Herpesvirus 1(BHV-1) belongs to the genus of Varicellovirus and the family of Herpesviridae which contains three main $\mathrm{gB}, \mathrm{gC}$ and $\mathrm{gD}$ genes. The objective of this study was to determine the relation between type of macroscopic lesions and bovine herpesvirus-1(BHV-1) infection; hence the aborted fetus specimens were initially prepared for PCR test. In this study, 23 of fetus samples, which were transferred to Veterinary Laboratories during 2009-2012, were assessed for BHV-1 with PCR in lung and spleen tissues and all of positive samples undergone histopathological study. The results indicated myocarditis and necrosis of cardiac tissue in 8 cases (42.1\%), and 6 cases encompassed interstitial lymphocytic pneumonia $(28.57 \%)$, whereas 5 cases revealed bronchopneumonia (23.8\%) and in 8 cases $(38.09 \%)$ severe interstitial edema was observed. In addition, the lesions may be associated with BHV-1, so that in brain tissue 9 cases (36\%) possessed encephalitis and necrosis, 8 cases (38.09\%) indicated interstitial nephritis, 2 cases $(9.52 \%)$ developed acute tubular necrosis, 2 cases $(9.52 \%)$ revealed vacuolar degeneration inrenal tubular epithelium, 1 case had (4.76\%) renal hemorrhage and in 3 cases (14.28\%) renal autolysis was observable. In liver, 10 cases $(47.61 \%)$ were affected to lymphocytic hepatitis, 5 cases (23.8\%) possessed necrotic hepatitis, 6 cases $(28.57 \%)$ of multifocal coagulative necrosis without inflammatory reaction and 3 cases $(14.28 \%)$ with lymphocytic portal hepatitis were observed. In this assessment, 10 specimens $(52.17 \%)$ of spleen tissues revealed necrosis and lymphatic tissues emptying and in 10 cases $(100 \%)$ severe enteritis, which may be associated with IBR, were recorded. This study suggests based on lesions in several organs induced by IBR virus and real time PCR confirmation there is direct correlation between virus and lesions, and in order to obtain more reliable results of IBR infection the histopathological examination may be efficient.
\end{abstract}

Keywords: Bovine Herpesvirus-1, Histopathological, Real Time PCR, Lung, Aborted Foetuses

\section{Introduction}

Infectious bovine rhinotracheitis (IBR) is highly contagious disease of bovine and some wild ruminants caused by bovine herpesvirus (BHV)-1 (family Herpesviridae, subfamily Alphaherpesvirinae). BHV-1 has worldwide distribution with significant difference in disease outbreak in multifarious geographical areas and with different management systems. BHV-1 infection causes significant economic losses to the livestock industry.
The virus has been associated with a variety of clinical disease manifestations including rhinotracheitis, vulvovaginitis, balanoposthitis, abortion, conjunctivitis and generalized systemic infection [1]. Naturally occurring BHV-1 abortions are usually observed at 4-8 months of gestation.

Infertility and abortions cause major losses in animal production. The IBR virus occurs in cattle herds throughout the world and can cause separate respiratory and genital syndromes, keratoconjunctivitis, meningoencephalitis in calves and abortions in cows. This pathogen 
causeendometritis, pyometra, abortion, infertility and considerable economic losses, particularly in endemic regions. The pathology related to BoHV-1-induced abortion has been well described.[2,3] As the placenta does not always develop lesions, an early pathological study hypothesized that placental changes were secondary to fetal infection,[3] with a slow cell-to-cell virus spread between cotyledons.[2] However, based on the extensive multifocal necrotic lesions that are consistently observed in the liver,[4]hematogenous spread via the umbilical vein appears the likely route, with virus spreading from the placenta to the fetus.[5] This is supported by an experimental challenge study published in 2007 where viral antigen was associated with extensive lesions in fetal liver and also with blood vessels in the fetal placenta, suggesting a hematogenous spread from the mother to the fetus.[6] However, the 2007 study was based on an intravenous challenge, so should be interpreted with caution. To date, there has been no molecular support for this theory in natural cases of BoHV-1 abortion.

Diagnosis of BHV-1 abortion is usually based on the presence of compatible histological lesions, virus isolation (VI), immunohistochemistry (IHC) for detection of viral antigen and polymerase chain reaction (PCR). VI may be successful in approximately one-third of cases of abortion showing histological lesions, since isolation is frequently hindered by fetal autolysis [7]. IHC has been used to detect BHV-1 in tissues with sensitivity similar to that of VI $[8,9]$. The PCR test is faster, easier to perform and the test of choice for rapid detection of BHV-1 in fetal tissue. Recently PCR has been used to detect BHV-1 virus in semen. Although this assay was not evaluated for disease diagnosis, the level of sensitivity described should allow its application for diagnostic purposes.

\section{Material and Methods}

\subsection{Sample Collection}

During 2009 to 2011, 23 aborted fetuses of cattle from different provinces of Iran and were collected to identify the possible causes of abortion and were investigated in the pathology laboratory. The numbers of samples have been related to the abortion problem in the provinces, interest rate of provincial experts and pursuit of ranchers.

\subsection{DNA Extraction}

In this present study the genomic DNA was isolated from lung and spleen contents of aborted fetuses using a genomic DNA purification kit (Invitrogen, Paisley, UK) according to the manufacturer's instructions. The total DNA was measured at $260 \mathrm{~nm}$ optical density according to the method described by Sambrook\& Russell (2001) [10].

\subsection{Real-Time PCR}

The DNA isolated from cell culture supernatants and clinical samples collected from ailing animals were subjected to routine PCR in $20 \mu \mathrm{L}$ of a reaction mixture containing a final concentration of 10 mMTris ( $\mathrm{pH} 9.0), 50$ $\mathrm{Mm} \mathrm{KCl}, 1.9 \mathrm{mM} \mathrm{MgCl} 2,0.2 \mathrm{mMdeoxy}$ nucleoside triphosphate, $\quad 0.1 \mu \mathrm{L} \quad$ primer $\quad \mathrm{P} 1$ (5'CTGCTGTTCGTAGCCCACAACG 3'), $0.1 \mu \mathrm{m}$ primer P2 (5' TGTGACTTGGTGCCCATGTCGC 3') and 1U of Taq Polymerase per reaction. All the reagents and primers were obtained from Bangalore Genie Ltd., Bangalore, India. The primer sequence is based on the sequence of BHV-1 glycoprotein $\mathrm{C}(\mathrm{gC})$ gene (AFSHAR and EAGLESOME, 1990). The PCR mixture was amplified by 38 repeated cycles: first 15 cycles at $95{ }^{\circ} \mathrm{C}$ for $1 \mathrm{~min}, 60^{\circ} \mathrm{C}$ for $1 \mathrm{~min}$ and $72{ }^{\circ} \mathrm{C}$ for $1 \mathrm{~min}$ and rest 23 cycles at $95{ }^{\circ} \mathrm{C}$ for $1 \mathrm{~min}$, $60{ }^{\circ} \mathrm{C}$ for $1 \mathrm{~min}$ and $72{ }^{\circ} \mathrm{C}$ for 1 min 4 seconds auto segment extension (VAN ENGELENBURG et al., 1993). Negative control reactions (reaction without template and reaction with BHV negative semen) were added to each set of PCR. The PCR products were analysed by agarose gel electrophoresis ( $2 \%$ agarose) using $5 \mu \mathrm{L}$ of the each PCR product mixed with $10 \mu \mathrm{L}$ of ethidium bromide dye.

In the present study we used a pair of sequence-specific primers for amplification of target DNA and a 5'-nuclease oligoprobe (Taqman) for the detection of amplified products. The oligoprobe was a single, sequence-specific oligonucleotide, labelled with two different flurophores, the reporter/donor, 5-carboxy fluorescein (FAM) at the 5' end, and the acceptor/quencher 6-carboxytetramethylrhodamine (TAMRA) at the 3' end. This real-time PCR assay was designed to detect the viral DNA of all BHV-1 strains, including subtype 1 and 2, from bovine semen as well as from clinical samples. Details of the primers and probes are as follows.

Primers and probe sequences. The primers and probe were selected as per LOVATO

et al. (2003) and ABRIL et al. (2004) and sequence were as follows:[11,12]

Primer gB-F: 5'-TGT GGA CCT AAA CCT CAC GGT3'

Primer gB-R: 5'-GTA GTC GAG CAG ACC CGT GTC3'

Taq Man probe: 5'- FAM AGG ACC GCG AGT TCT TGC CGC TAMRA-3,

\subsection{Histopathology}

Tissue samples from all cases where BHV-1 DNA was detected by real-time PCR were analyzed using histopathological methods. Samples were fixed in $10 \%$ formalin for at least $24 \mathrm{hr}$ and then embedded in paraffin wax blocks. Five-micron sections were cut using a microtome, placed on slides, and stained with hematoxylin and eosin (HE) by standard methods

\section{Results}

\subsection{Real Time- PCR Findings}

According to PCR test process, 23 fetuses were positive 
for BHV-1 which their features are available at table..... Furthermore, all of BHV-1 positive samples were undergone histipathological examination in Veterinary Laboratory. Of 23 specimens, 9 organs were assessed because available technologies, thus certain frequency and relative frequency of observed lesions are depicted at table ... based on affected organs.

\subsection{Histopathological Findings}

Histopathological examination in case of quality and presence of lesions and tissues were determined as below. (The definite and relative frequencies of lesions are depicted at table $(1,2,3)$.Heart: hyperemia, lymphocytic vacuities, myocarditis, necrosis (Fig 1A).Cerebellum: cerebellar edema, demyelination $+\mathrm{PVC}$ and hyperemia (Fig $1 \mathrm{~B}$ and 1C).Brain: multifocal liquefactive necrosis, edema, non-suppurative meningitis, PVC, diffuse gliosis, submeningal hemorrhage, autolysis and hyperemia (Fig 1D).Lung: interstitial lymphocytic pneumonia, bronchopneumonia interstitial edema, mild hemorrhage, numerous colonies of Bacillus bacteria with multiple vascular thrombosis, perivascular hemorrhage+ mononuclear vasculitis and hyperemia (Fig 1E).Kidney: interstitial nephritis,ATN, tubular epithelial vacuolar degeneration, renal hemorrhage, autolysis and hyperemia(Fig 1F).Liver: lymphocytic hepatitis, necrotic hepatitis, multifocal coagulative necrosis, portal hepatitis, fatty change, vascular thrombosis (Fig 1Gand $1 \mathrm{H}$ ).Spleen: megakaryocytosis, lymphoid cell depletion, subscapular hemorrhage, perivasculitis, autolysis and hyperemia (Fig 1I).Thymus: mild hemorrhage. Intestine: enteritis.

Table1: Differences in the frequency of observed lesions in bovine fetuses aborted by IBR.

\begin{tabular}{ll}
\hline The list of names of organs & Frequency of observed lesions \\
\hline Heart & $19(82.6 \%)$ \\
Cerebellum & $6(26.08 \%)$ \\
Brain & $17(73.91 \%)$ \\
Lung & $21(91.30 \%)$ \\
Kidney & $21(91.30 \%)$ \\
Liver & $21(91.30 \%)$ \\
Spleen & $23(100 \%)$ \\
Intestinal & $10(43.47 \%)$ \\
Thymus & $1(4.34 \%)$ \\
\hline
\end{tabular}

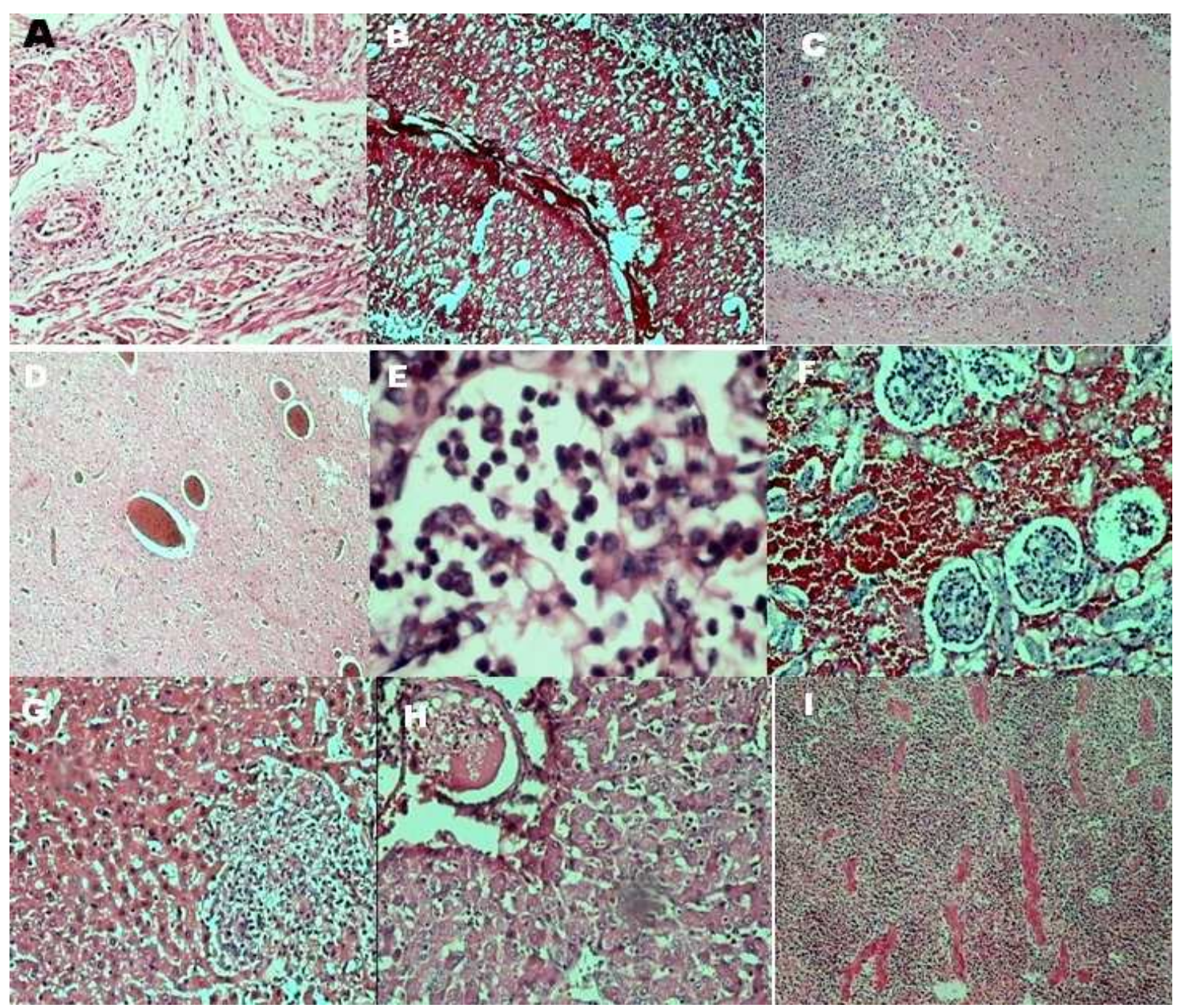

Fig 1: Histopathological lesion different types of organs in bovine fetuses aborted by IBR: A:Histologic examination of the heartrevealeddiffuse interstitial mononuclear cell my ocarditis,B: Edemaof the cerebellum; status spongiosus, C:The swelling of peri-Purkinje cellular in cerebellum,D:Cerebral edema, E:Suppurativepneumonia,; F:ATN and Renal interstitial haemorrhage, G: Necrotic hepatitis, H:thrombosis endovascular in the portal space, I:Decreaseinspleenlymphocytes. 
Table2: The complete range of histopathological lesion types of heart, cerebellum,brain and lung in bovine fetuses aborted byIBR

\begin{tabular}{|c|c|c|c|c|c|c|c|}
\hline Heart & Fr. & Cerebellum & Fr. & Brain & Fr. & Lung & Fr. \\
\hline Necrosis & $8(42.10 \%)$ & Edema & $4(66.6 \%)$ & $\begin{array}{l}\text { Multifocal } \\
\text { liquifactive } \\
\text { necrosis }\end{array}$ & $4(23.52 \%)$ & Interstitial lymphocytic pneumonia & $6(28.57 \%)$ \\
\hline Myocarditis & $8(42.10 \%)$ & Demyelination $+\mathrm{PVC}$ & $2(33.3 \%)$ & Edema & $5(29.41 \%)$ & Broncho pneumonia & $5(23.8 \%)$ \\
\hline $\begin{array}{l}\text { Lymphocytic } \\
\text { Vasculitis }\end{array}$ & $1(5.26 \%)$ & Hyperemia & $3(50 \%)$ & $\begin{array}{l}\text { Non } \\
\text { suppurative } \\
\text { meningitis }\end{array}$ & $1(5.88 \%)$ & Interstitial edema & $8(38.09 \%)$ \\
\hline \multirow[t]{5}{*}{ Hyperemia } & $5(26.31 \%)$ & & & $\mathrm{PVC}$ & $3(17.64 \%)$ & $\begin{array}{l}\text { Mild hemorrhage together with } \\
\text { colony of bacteria }\end{array}$ & $1(4.76 \%)$ \\
\hline & & & & Diffuse gliosis & $1(5.88 \%)$ & $\begin{array}{l}\text { Perivascular } \\
\text { hemorrhage+mononuclearvasculitis }\end{array}$ & $1(4.76 \%)$ \\
\hline & & & & $\begin{array}{l}\text { Submeningial } \\
\text { hemorrhage }\end{array}$ & $1(5.88 \%)$ & Hypermia & $8(38.09 \%)$ \\
\hline & & & & Autolysis & $3(17.64 \%)$ & & \\
\hline & & & & Hypermia & $7(41.17 \%)$ & & \\
\hline
\end{tabular}

Table3: The complete range of histopathological lesion types of kidney, liver,spleen,intestinal and thymus in bovine fetusesaborted by IBR

\begin{tabular}{|c|c|c|c|c|c|c|c|c|c|}
\hline Kidney & Fr. & Liver & Fr. & Spleen & Fr. & Intestinal & Fr. & Thymus & Fr. \\
\hline $\begin{array}{l}\text { Intestinal } \\
\text { nephritis }\end{array}$ & $8(38.09 \%)$ & $\begin{array}{l}\text { Necrotic } \\
\text { hepatitis }\end{array}$ & $5(23.8 \%)$ & Megakaryocytosis & $5(21.73 \%)$ & Enteritis & $10(100 \%)$ & $\begin{array}{l}\text { Mild } \\
\text { hemorrhage }\end{array}$ & $1(1005)$ \\
\hline ATN & $2(9.52 \%)$ & $\begin{array}{l}\text { Lymphocytic } \\
\text { hepatitis }\end{array}$ & $10(47.61 \%)$ & $\begin{array}{l}\text { Lymphoid cell } \\
\text { depletion }\end{array}$ & $12(52.17 \%)$ & & & & \\
\hline $\begin{array}{l}\text { Tubular } \\
\text { epithelial } \\
\text { vacuolar } \\
\text { degeneration }\end{array}$ & $2(9.52 \%)$ & $\begin{array}{l}\text { Multifocal } \\
\text { coagulative } \\
\text { necrosis }\end{array}$ & $6(28.57 \%)$ & $\begin{array}{l}\text { Subcapsular } \\
\text { hemorrhage }\end{array}$ & $1(4.345 \%)$ & & & & \\
\hline Autolysis & $1(4.76 \%)$ & $\begin{array}{l}\text { Portal } \\
\text { hepatitis }\end{array}$ & $3(14.28 \%)$ & Perivaculitis & $1(4.345 \%)$ & & & & \\
\hline Hyperemia & $3(14.28 \%)$ & Fatty change & $2(9.52 \%)$ & Autolysis & $1(4.345 \%)$ & & & & \\
\hline $\begin{array}{l}\text { Renal } \\
\text { hemorrhage }\end{array}$ & $10(47.61 \%)$ & $\begin{array}{l}\text { Vascular } \\
\text { thrombosis }\end{array}$ & $1(4.76 \%)$ & Hypermia & $6(26.08 \%)$ & & & & \\
\hline
\end{tabular}

\section{Discussion}

In a study by Jubb and Anderson on aborted fetuses following IBR infection indicated fetuses developed edematous and progressed autolysis[13,14]. In this assessment, $26.08 \%$ (6 cases) of fetuses encompassed autolysis lesions. In a study in 2004 by Yamini et al. showed that the etiology of aborted fetuses of 592 cattle 82 cases $(5.07 \%)$ compromised arcanobacter Iumpyogenesis, 55 cases $(3.4 \%)$ possessed protozoa and 52 cases $(3.2 \%)$ revealed IBR, representing the first viral agent for abortion was IBR[15].

According to this study, most of deaths in fetuses prior to parturition had no infection cause, and non-infectious causes including genetic disorders, teratogenesis, dietary disorders, poisonous plants, hormonal disorders, etc may be important. Furthermore, according to Anderson the age of abortion due to IBR occurs in third trimester or second trimester which in present study it was mostly recorded in third trimester. In addition, Jubb expressed abortions hardly occur in less than 5 months of gestation following BHV-1 infection [13]. In a study by Yamini et al, reported the aborted fetuses due to IBR develop cardiac lesions as myocarditis [15] because most of cases (42.10\%) possessed myocarditis and necrosis lesions, indicating probably the IBR agent could trigger such lesions. In present study, the brain lesions comprised 4 cases $(23.52 \%)$ of liquefactive multifocal necrosis, 3 cases (17.64\%) of PVC, 1 case (5.88\%) of sub-meningeal hemorrhage and some lesions as encephalitis and necrosis were observed which the findings had been determined by Jubb (2007) as well.

Safarpoordeh-kordi(2013), demonstrated the pneumonia lesions are the most common forms in aborted fetuses [16]. In present study majority of respiratory system microscopic lesions of aborted fetuses were recorded as interstitial bronchopneumonia, so that it resulted in filling the bronchoalveolar spaces by numerous neutrophils, macrophages and yellow meconium compounds, related to biliary secretions, that vast areas of lobes were affected and 
contained Brucellaabortus and arcane bacterium pyogenesis, thereby the most significant causes of interstitial pneumonia are IBR and PI3. In present study, in 6 cases $(28.57 \%)$ interstitial lymphocytic pneumonia, 5 cases (23.8\%) bronchopneumonia, 8 cases $(38.9 \%)$ severe interstitial edema were recorded. Additionally, those 6 cases of interstitial pneumonia were definitely associated with BHV-1. In case of renal lesions in a study by Yamini et al and Jubb indicated nephritis and necrosis in kidneys, whereas in present study 8 cases $(38.09 \%)$ of interstitial nephritis, 2 cases $(9.52 \%)$ of acute tubular necrosis (ATN), vacuolar degeneration of tubular epithelium in 2 cases $(9.52 \%)$, renal hemorrhage in 1 case $(4.76 \%)$ and 3 cases (14.28\%) of autolysis were observed. Thus, the role of other aborting causes such as protozoa (neospora) which causes lymphoid cells infiltration in several tissues should be taken in to consideration.

Furthermore, in liver, Anderson and Jubb and Yamini expressed some lesions as small necrotic foci, hepatitis and mononuclear cells infiltration. In present study, 10 cases (47.61\%) had lymphocytic hepatitis, 5 cases $(23.8 \%)$ necrotic hepatitis, 6 cases $(28.57 \%)$ multifocal coagulative necrosis without inflammatory reaction and 3 cases (14.28\%) of lymphocytic portal hepatitis were observed. On the other hand, most of hepatic lesions were included necrosis and hepatitis and often accompanied by IBR $[13,14,15]$. In spleen, according to Jubb and Anderson the lesions included lymphoid necrosis and necrotic foci with slight cellular infiltration. In present assessment, 12 cases $(52.17 \%)$ possessed necrosis and lymphoid tissues emptying which may be associated with IBR [13]. In intestines, according to Jubb, the microscopic lesions contained necrotic foci with slight cellular infiltration, hyperemia and dilation and had transparent layer of fibrinous exudate on serous surface. In present study, 10 cases $(100 \%)$ showed enteritis. According to divers lesions in tissues affected to IBR, the etiology of such abortions in cattle through PCR was ascertainedas BHV agent and histopathological lesions confirmed such findings as well.

\section{Conclusion}

In conclusion, the determined lesions in various organs of aborted fetuses, in which IBR virus was determined through PCR, indicated that between this virus and lesions in aborted fetuses was correspondent correlation. Finally, in order to obtain more information in case of confirming the IBR infection as abortion inducing agent the histopathological examination was beneficial.

\section{References}

[1] Gibbs EPJ, ReveyemamuMM.Bovine herpesviruses. part 1. Bovine herpesvirus-1. Vet Bull1977;47:317-343.

[2] Kendrick JW, Schneider L, Straub OC. Placental reac -tion to the infectious bovine rhinotracheitis-infectious pustularvulvovaginitis virus. Am J Vet Res1971;32:10451051.

[3] Molello JA, Chow TL, Owen N, Jensen R. Placental pathology. V. Placental lesions of cattle experimentally infected with infectious bovine rhinotracheitis virus. Am J Vet Res 1966; 27: 907-915.

[4] Owen NV, Chow TL, MolelloJA. Bovine fetal lesions experimentally produced by infectious bovine rhinotracheitis virus. Am J Vet Res 1964;25:1617-1626

[5] Rodger SM, Murray J, Underwood C, Buxton D.Microscopical lesions and antigen distribution in bovine fetal tissues and placentae following experimental infection with bovine herpesvirus-1 during pregnancy. J Comp Pathol2007;137: 94-101.

[6] Smith KC.Herpesviral abortion in domestic animals. Vet J 1997;153:253-268.

[7] Smith KC, Whitwell KE, Blunden AS. Equine herpesvirus-1 abortion: atypical cases with lesions largely or wholly restricted to the placenta. Equine Vet J 2004;36:79-82.

[8] Mahajan V, Banga HS, Deka D, Filia G, Gupta A.Comparison of DiagnosticTests for Diagnosis of InfectiousBovineRhinotracheitis in NaturalCases of BovineAbortion. J Comp Pathol.2013 Jul 22.pii: S00219975(13)00083-2. doi: 10.1016/j.jcpa.2013.05.002. [Epub ahead of print]

[9] Wang J, O'Keefe J, Orr D. An international inter-laboratory ring trial to evaluate a real-time PCR assay for the detection of bovine herpesvirus 1 in extended bovine semen. Vet Microbiol2008;126:11-19.

[10] Sambrook J, Russell DW. Mole-cular Cloning: A Laboratory Manual. Cold Spring Harbor Laboratory Press, New York,2001, pp. 544-553.

[11] Abril C, Eengles M, Liman A, Hileb M, Albini S. Both viral and host factors contribute to neurovirulence of bovine herpesviruses 1 and 5 in interferon receptor-deficient mice. Virology Journal 2004;78, 3644-3653.

[12] Lovato L, Inman M, Henderson G, Doster A, Jones C. Infection of cattle with a bovine herpesvirus 1 strain that contains a mutation in the latency related gene leads to increased apoptosis in trigeminal ganglia during the transition from acute infection to latency. Virology Journal 2003;77, 4848-4857.

[13] Jubb k ,palmer's.Pathology of domestic animals,fifth edition,2007,volume 1,pp:429-430

[14] Yamini B, Mullaney TP, Patterson JS, Fitzgerald SD, SteficekBA.Causes of bovine abortion in the north-central United States:Survey of 1618 cases(1983-2001), The bovine practioner2002;38:59-64

[15] Anderson ML.Infectious causes of bovine abortion during mid- to late-gestation. Theriogenology2007;68(3):474-86.

[16] Safarpoordehkordi F, Haghighi N, Momtazm H,rafsanjaniS, Momeni M.Conventional vs real-time pcr for detection of bovine herpes virus type 1 in aborted bovine, buffalo and camel fetuses. Bulgarian Journal of Veterinary Medicine 2013;16( 2):102-111 